\title{
Students' Ability in Making Motion Graphics Learning Videos
}

\author{
Rianto $^{1}$, Indrya Mulyaningsih ${ }^{2}$ \\ \{riantompd@gmail.com ${ }^{1}$, indrya.m@gmail.com² ${ }^{2}$,
}

IAIN Syekh Nurjati, Jalan Perjuangan By Pass Sunyaragi Cirebon, Indonesia

\begin{abstract}
Learning media is one of the supporting aspects in achieving learning success. Motion graphics are present as one of the Indonesian language learning media as an alternative distance learning media. This study aims to explain the ability of Indonesian Language Tadris students in the fifth semester in making motion graphics videos as a medium for learning Indonesian. The data obtained in this descriptive qualitative research are in the form of 11 Indonesian language learning motion graphics learning videos made in groups by Indonesian students in the fifth semester of the academic year 2021-2022. Data collection uses notetaking and interview techniques. The research instrument used guidelines for making motion graphics learning videos. The validity of the data using triangulation theory, data sources, and methods. The analysis obtained shows that $23 \%$ of the motion graphics made by students do not meet the standards. Aspects that are assessed are content or content, letters, color combinations or layouts, and sound effects.
\end{abstract}

Keywords: Motion Grapics; Learning Video

\section{Introduction}

One important component in the learning process is the learning media. This learning media can support the success of learning because according to its function the learning media is not only a tool but also a carrier of information or messages needed by students [1]. This success is of course also supported by the ability of Indonesian tadris students as prospective Indonesian language teachers in making learning media. This is in line with the statement that in the learning process the teacher does not only play a role in providing information. Teachers must be able to understand the diversity of students' abilities in learning. So teachers are required to be able to provide and use learning media in accordance with the material so that students are more effective and efficient in learning [2]. For this reason, teachers must have sufficient skills, knowledge, and understanding of learning media [3]. One of the effective learning media used is learning video in the form of motion graphics.

Motion graphics are a combination of graphics or writing, animation (moving images), and audio or sound, either background music or narration. This is in line with the statement that motion graphics is a branch of graphic design that is concerned with movement and graphics as the art of drawing on a computer by combining illustration, typography, photography, and videography by using animation techniques that have continuity so that they move and look 
alive [4]. According to Michael Betancourt, a film expert, motion graphics are media in the form of video or animation technology combined with audio that will create the illusion of motion with multimedia output [5]. This motion graphics learning media is certainly very important during distance learning. The use of animated motion graphics videos will make it easier for students in the teaching and learning process. Students will be able to absorb material information through motion graphics videos [6]. Because according to the principle of the learning media itself, motion graphics have audio and visual aspects that can be recorded by students' memories when studying. The use of learning media according to a statement from Computer Technology Research (CTR) states that $208 \%$ of a person will remember what he saw, 30\% heard, 50\% what he saw and heard, and $80 \%$ when he saw, heard and did [7].

Aspects of assessment on learning media in the form of motion graphics consist of the suitability of appearance, sound clarity, components of music presentation, material writing, and presentation of student understanding [8]. In this study, the assessment aspect in making motion graphics learning media at least refers to the standard aspects of content or content, font selection and size, display color and sound effects as well as the narration delivered. In the aspect of content or content, it must be in accordance with the material being taught. The suitability of the content conveyed is the first important point, because this message or information will be the basic capital for students to gain insight into the knowledge being studied. In accordance with its main function, learning media that are integrated with technology such as motion graphics are made to increase students' understanding [9].

The aspect of selection and size of the typeface must be in accordance with the standard of legibility. Learning media must of course be easy to understand through the visual aspects of typography that are delivered. This typography should be able to convey a message that is easy to read. In principle, typography has several important points to note, first, legibility, namely the legibility of letters based on the typeface. Second, readability is the relationship of one letter to another letter. Third, visibility, a measure of how easy the letters are to read at a certain distance. Fourth, clarity, which is easy for readers to understand [10]. In the aspect of display color, a color that is not too flashy or dark should be chosen so that it is easy to read. Color is light that is reflected by objects and is received by the retina of the eye which then reacts thereby changing the perception of the viewer [11]. While on the sound aspect, of course, the sound of both background music and narration must be clear to match the requirements of good learning media.

\section{Methodology}

The This type of qualitative research uses a descriptive method, namely analyzing learning videos made by students. The research data was used in the form of 15 motion graphics videos made by Indonesian students in the fifth semester of the academic year 2021-2022. The reason for choosing research subjects is because this course is taught by researchers. Data were collected by means of interviews and note-taking techniques. The data collection instruments used interview instruments and guidelines for making motion graphics learning videos. For the validity of the data used triangulation theory, sources, and methods. The triangulation of this theory refers to the rules for making motion graphics learning videos. Source triangulation refers to motion graphics learning videos made by fifth-semester students of class $\mathrm{C}$ in groups when attending lectures on the development of Indonesian language and literature learning media. While method triangulation refers to the method used when collecting and analyzing 
data. The stages of analysis in this study include collecting motion graphics learning videos via the google drive link, analyzing motion graphics learning videos according to the guidelines for making, and concluding.

\section{Result and Discussion}

The It should be noted that the motion graphics learning video data made by students in groups are heterogeneous in terms of content, meaning that these motion graphics are made from various grade levels in junior high and high school. The Indonesian language learning materials also vary at several grade levels. This is done so that students are more varied and more motivated to be able to make learning media at every level of education [12].

The following are the results of the analysis of the eleven videos of group work from making motion graphics obtained from the fifth semester of class $\mathrm{C}$. The data will be analyzed into five groups according to the completeness of each component.

Table 1. Motion Graphic Data Component

\begin{tabular}{|c|c|c|c|c|c|}
\hline \multirow[t]{2}{*}{ No } & \multirow[t]{2}{*}{ Name Group } & \multicolumn{4}{|c|}{ Component } \\
\hline & & Material & Typhography & Layout Color & Sounds Effect \\
\hline 1 & A & $\sqrt{ }$ & $\sqrt{ }$ & $\sqrt{ }$ & $\sqrt{ }$ \\
\hline 2 & B & - & $\sqrt{ }$ & $\sqrt{ }$ & $\sqrt{ }$ \\
\hline 3 & $\mathrm{C}$ & $\sqrt{ }$ & $\sqrt{ }$ & - & $\sqrt{ }$ \\
\hline 4 & D & $\sqrt{ }$ & $\sqrt{ }$ & $\sqrt{ }$ & - \\
\hline 5 & $\mathrm{E}$ & $\sqrt{ }$ & - & $\sqrt{ }$ & $\sqrt{ }$ \\
\hline 6 & $\mathrm{~F}$ & $\sqrt{ }$ & $\sqrt{ }$ & $\sqrt{ }$ & $\sqrt{ }$ \\
\hline 7 & G & $\sqrt{ }$ & $\sqrt{ }$ & $\sqrt{ }$ & - \\
\hline 8 & $\mathrm{H}$ & $\sqrt{ }$ & - & $\sqrt{ }$ & $\sqrt{ }$ \\
\hline 9 & I & $\sqrt{ }$ & $\sqrt{ }$ & $\sqrt{ }$ & - \\
\hline 10 & $\mathrm{~J}$ & $\sqrt{ }$ & - & $\sqrt{ }$ & $\sqrt{ }$ \\
\hline 11 & K & $\sqrt{ }$ & - & $\sqrt{ }$ & - \\
\hline
\end{tabular}

\subsection{Complete Aspect}
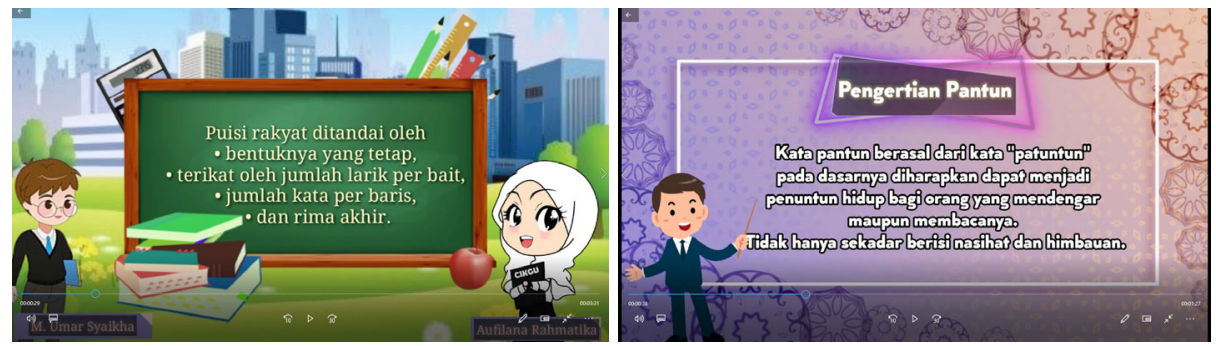

Fig. 1. The results of the motion graphics of groups A and F

The results of group A's motion graphics are already very good. It can be seen from the completeness of the standard aspects requested. in terms of material on Folk Poetry presented for the 7th grade even semester. The material presented is complete consisting of understanding, characteristics, and types of folk poetry. Learning appreciation of literature to write folk poetry is contained in the 2013 Curriculum for learning Indonesian in junior high school (SMP) class VII semester II, students are required to be skilled at writing folk poetry. 
Learning in junior high school class VII semester II in the 2013 curriculum there is an appreciation of folk poetry. Students are guided to skillfully write folk poetry according to basic competencies [13]. Overall the material is delivered very well considering the time. In addition, in the beginning, there is a greeting to students and at the end, it provides motivation to keep the spirit of learning. With learning media, students will be more motivated to learn, encourage students to be more active and learning will be more effective and efficient [14].

In terms of size and type of font used. Overall it is good because it is seen or read by listeners of the motion graphics video. The combination of bright colors also dominates in this motion graph because the age of students around 13-14 years old will attract attention and motivation to learn. Because it is in accordance with the function of the media in learning activities, namely a means of providing visual experiences to students in order to increase learning motivation, clarify and facilitate abstract concepts [15]. The sound used is also very good because it uses clear intonation, pronunciation, and volume plus good background music effects in every part of the motion graphic.

\subsection{Material Aspect}

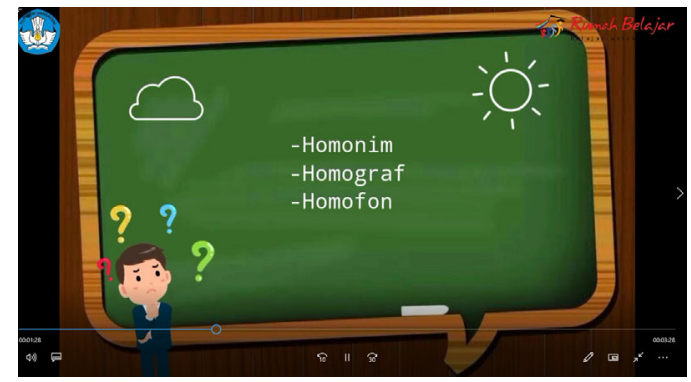

Fig. 2. The results of the motion graphics of groups B

The results of the motion graphics of group B are good. However, there is one aspect that is lacking, namely the learning material. Specific learning materials about homonyms, homographs, and homophones are in the education unit level curriculum, while the 2013 curriculum includes linguistic materials. Learning media must be selected according to the specified instructional objectives [16]. A very good level of material achievement in motion graphics is the suitability of the material with core competencies and basic competencies, this is in accordance with the statement that the most important thing in developing learning media is conformity with learning objectives [17].

The combination of letters, the color layout is very good plus the motion effect that dominates it will be very interesting for students to learn. This is in accordance with the concept of motion graphics itself, which is a technique of combining visual media, which is delivered dynamically and attractively [18]. And according to Simamora's opinion that learning media should increase learning motivation and provide a stimulus to remember what has been learned [19]. 


\subsection{Layout Color Aspect}

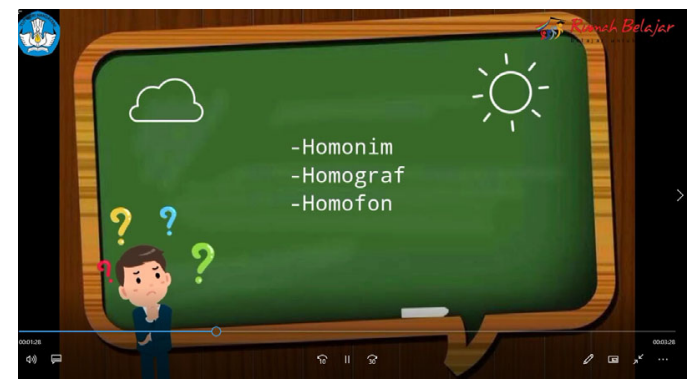

Fig. 3. The results of the motion graphics of groups $\mathrm{C}$

The results of the motion graphics of group $\mathrm{C}$ are good. In terms of the material, it is complete, namely about the meaning, elements, types of poetry, and even explained how to write and read good poetry. This knowledge competence will lead to the achievement of poetry writing competence in basic competence 4.8, namely presenting ideas, feelings, opinions in the form of poetry texts in writing/oral by paying attention to the building blocks of poetry [20]. It was also conveyed that additional poetry musicals should be given, examples of what videos of poetry musical performances should look like. From the sound, it is clear, both the voice of the narrator and the background music. However, the most significant drawback of group $\mathrm{C}$ motion graphics is in terms of appearance or color layout. At the time of delivery of the material, there was no slide movement according to the sub-material explained so that it looked stiff and monotonous.

The main supporting elements of multimedia motion graphics include images which are elements of the layout. By looking at the pictures on the material, it will have a better impact than just reading the text [21]. In addition, motion graphic images also have elements of motion from objects in the video. It is hoped that this will attract attention and be effective in the speed of capturing information because the illustrations in the motion graphics will become the illusion of students [22]. Or in accordance with the concept of motion graphics, namely the use of video or animation as an illusion or transformation [23]. In addition to images and motion, colors in motion graphics can also contribute to the speed of understanding the material. Wiyani and Barnawi stated that shapes and colors can improve concentration and understanding of the material [24].

\subsection{Typography Aspect}
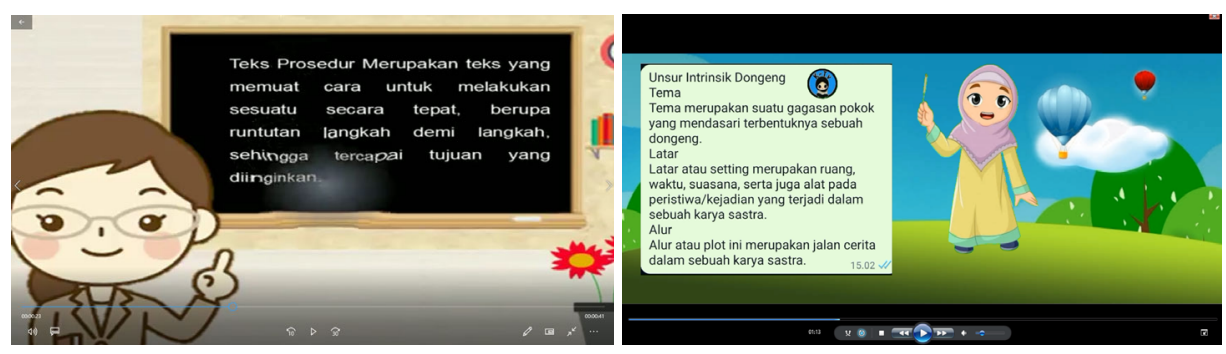


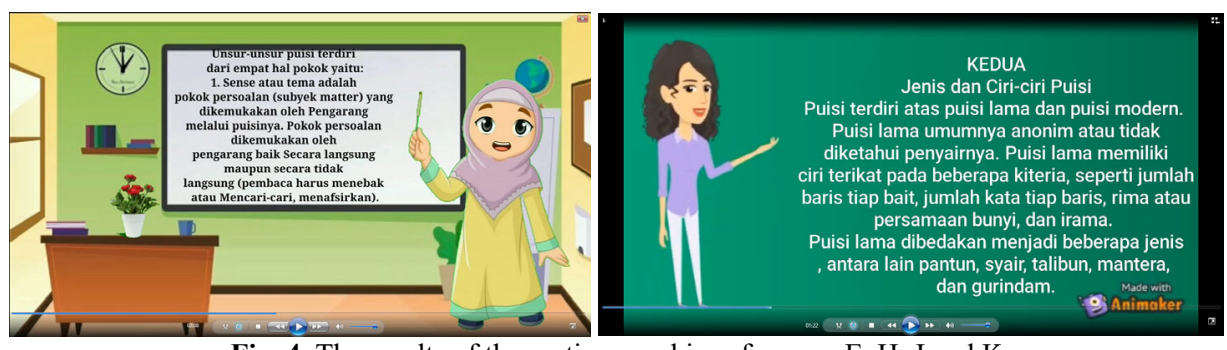

Fig. 4. The results of the motion graphics of groups $\mathrm{E}, \mathrm{H}, \mathrm{J}$ and $\mathrm{K}$

From the four results of making motion graphics groups $\mathrm{E}, \mathrm{H}, \mathrm{J}$ and $\mathrm{K}$ are quite good. Because of paying attention to the quality of the material, color layout, and clear sound. However, the weakness of this motion graphic video is that the points presented are too textual and no examples are presented so that in terms of appearance it is less attractive. According to Puspita, PowerPoint media containing pictures and sound effects will increase students' enthusiasm for learning so they don't get bored in following the learning process and help students more easily grasp the material [25]. While the graphic itself is the basis for setting aspects of other motion graphics because the writing of this letter is the beginning of the attention of the other components [21]. The selection of this information display will then become typography in motion graphics. Typography not only gives meaning to material ideas but also has an aesthetic and functional value [26]

\subsection{Sounds Effect Aspect}
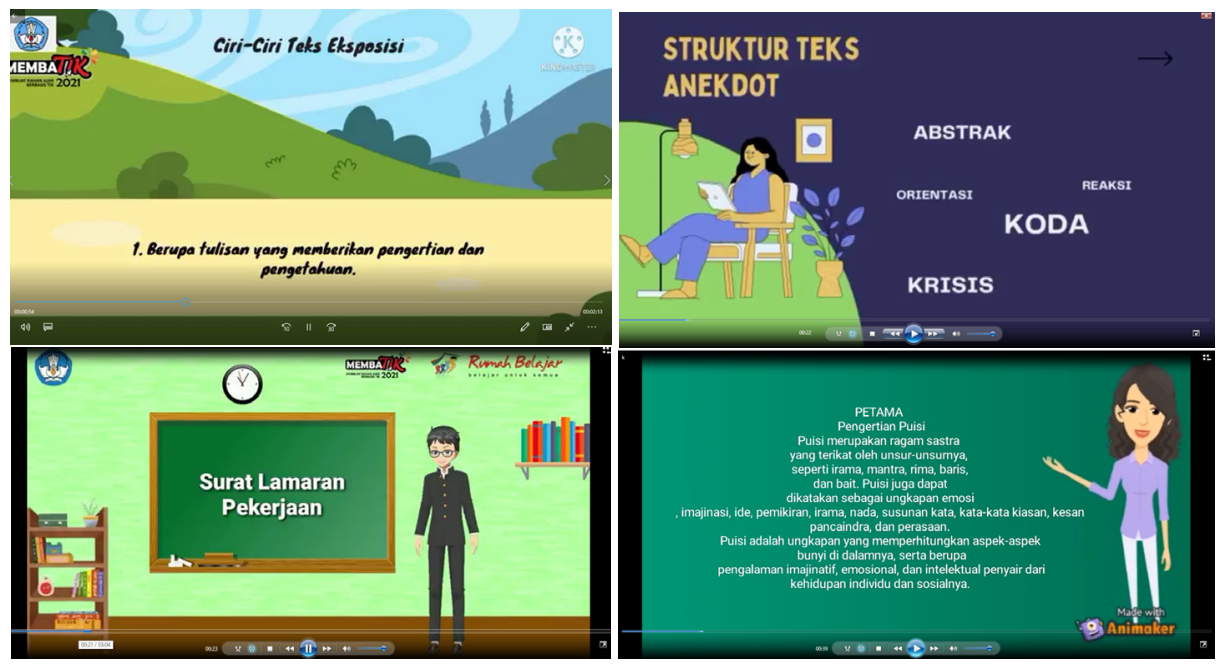

Fig. 5. The results of the motion graphics of groups D, G, I and K

The results of the motion graphics of groups D, G, I, and $\mathrm{K}$ are quite good. In terms of material, the exposition text, anecdotal text, job application letters, and poetry are complete, the color or layout is quite good, and the selection of the right type and form of text. However, the sound aspect of the motion graphics in group D is not given a narrator, so it will reduce the 
aspect of the motion graphics assessment itself. The presentation of motion graphics or animated videos must present complete elements, namely sound, graphics, and text [27]. The potential learning media to improve the ability to write expository texts by students is audiovisual media. Media with audio-visual has the ability to activate the senses of hearing and sight [28]. So that the audio element in the form of a narrator is very important in learning exposition text. In the motion graphics video, group $\mathrm{G}$ is the same, there is no element of the narrator's voice.

The motion graphics videos of group I are basically good because they give animation effects to the characters, but changing the sound effects and background music are too loud so that it interferes with the narrator aspect. The learning media made must have good criteria, for example on the motion graphics the narrator's voice must be clear without interference from other sound effects [29]. The group $\mathrm{K}$ video does not have background music elements so the sound seems monotonous. Illustrations in the form of background music on learning media can change the atmosphere of the learning environment to be fun so that students are enthusiastic about learning [30].

\section{Conlusion}

Based on the analysis that has been done, $23 \%$ of the motion graphics videos made by students are incomplete. Aspects of component assessment consist of aspects of content or content, letters, color combinations or layouts, and sound effects. From the component analysis, there is still one group that is not in accordance with the material contained in the curriculum. One group in terms of layout or color is still monotonous. Four groups with voices that are still unclear, and typography that is still lacking. However, there were two groups that met the four components very well in the motion graphics assessment.

\section{References}

[1] C. Riyana, Media Pembelajaran, 2nd ed. Jakarta: Kemenag RI, 2021.

[2] R. Abdullah, "Pembelajaran Dalam Perspektif Kreativitas Guru Dalam Pemanfaatan Media Pembelajaran," Lantanida J., vol. 4, no. 1, p. 35, 2017, doi: 10.22373/lj.v4i1.1866.

[3] N. D. Shalikhah, "Media Pembelajaran Interaktif Lectora Inspire sebagai Inovasi Pembelajaran," War. LPM, vol. 20, no. 1, pp. 9-16, 2017, doi: 10.23917/warta.v19i3.2842.

[4] E. S. Romadonah and I. N. Maharani, "MOTIONS GRAPHIC SEBAGAI MEDIA PEMBELAJARAN," J. Utile, vol. V, no. 2, pp. 115-122, 2019.

[5] Damayanti and H. Wulandari, "Pengembangan Media Pembelajaran Motion Graphic Untuk Siswa Kelas XI Pada Desain Multimedia di SMKN 1 Cibadak," $J$. Kependidikan, pp. 22-31, 2018.

[6] D. A. A. Revlinasari, I. N. S. Degeng, and A. Wedi, "Animasi Motion Graphics Dinamika Litosfer Pada Mata Pelajaran Geografi Kelas X Sma," JKTP J. Kaji. Teknol. Pendidik., vol. 4, no. 2, pp. 168-177, 2021, doi: 10.17977/um038v4i22021p168.

[7] Munir, Multimedia Konsep Dan Aplikasi Dalam Pendidikan. Bandung: Alfabeta, 2013.

[8] I. Sa'adah, E. S. Purnomo, and R. Suharso, "Pengembangan Media Video Motion Graphic Sejarah Pemerintahan Herman Willem Daendels (1808-1811) dalam 
Pembelajaran Sejarah Indonesia Untuk Meningkatkan Minat Belajar Siswa Untuk SMA,” Indones. J. Hist. Educ., vol. 5, no. 1, pp. 25-31, 2017.

[9] M. D. Nastiti and A. N. Tompunu, "Animasi 2D ( Motion Graphic ) Sebagai Media," J. EL Sains, vol. 3, no. 1, pp. 37-42, 2021.

[10] P. Sulistiyawati, D. P. Prabowo, D. K. Visual, F. I. Komputer, U. Dian, and N. Semarang, "PERANCANGAN MEDIA PEMBELAJARAN BERBASIS AUDIO VISUAL UNTUK MATA KULIAH TIPOGRAFI PADA PROGRAM STUDI,” pp. 69-80.

[11] A. U. Siahaan, H. A. Putri, and A. Dzikri, "Motion Graphic untuk Pengenalan Warna Dalam Bahasa Inggris," J. Integr., vol. 13, no. 1, pp. 32-39, 2021, doi: 10.30871/ji.v13i1.2465.

[12] I. Mulyaningsih, "Ability of Indonesian Teachers Candidates in Preparing a Lesson Plans," BAHTERA J. Pendidik. Bhs. dan Sastra, vol. 19, no. 2, pp. 218-234, 2020, doi: 10.21009/bahtera.192.03.

[13] N. Yanti, A. Gafar, and A. Rofii, "Pengaruh Penggunaan Media Gambar Terhadap Kemampuan Menulis Puisi Rakyat Siswa Kelas Vii Smp Negeri 6 Kota Jambi Tahun Ajaran 2017/2018," Aksara J. Ilm. Pendidik. Bhs. dan Sastra Indones., vol. 2, no. 2, p. 67, 2018, doi: 10.33087/aksara.v2i2.74.

[14] T. Tafonao, "Peranan Media Pembelajaran Dalam Meningkatkan Minat Belajar Mahasiswa," J. Komun. Pendidik., vol. 2, no. 2, p. 103, 2018, doi: 10.32585/jkp.v2i2.113.

[15] M. Miftah, "Fungsi, Dan Peran Media Pembelajaran Sebagai Upaya Peningkatan Kemampuan Belajar Siswa," J. Kwangsan, vol. 1, no. 2, p. 95, 2013, doi: 10.31800/jtpk.v1n2.p95--105.

[16] T. Nurrita, "PENGEMBANGAN MEDIA PEMBELAJARAN UNTUK MENINGKATKAN HASIL BELAJAR SISWA,” J. Misykat, vol. 3, no. 1, pp. 171187, 2018, doi: 10.1088/1742-6596/1321/2/022099.

[17] U. Hasanah and L. Nulhakim, "Pengembangan Media Pembelajaran Film Animasi Sebagai Media Pembelajaran Konsep Fotosintesis," J. Penelit. dan Pembelajaran IPA, vol. 1, no. 1, p. 91, 2015, doi: 10.30870/jppi.v1i1.283.

[18] M. I. Nawawi, "Pengaruh Media Pembelajaran terhadap Motivasi Belajar: Tinjauan berdasarkan Karakter Generasi Z,” J. Penelit. dan Pengkaj. Ilmu Pendidik. e-Saintika, vol. 4, no. 2, p. 197, 2020, doi: 10.36312/e-saintika.v4i2.216.

[19] R. Firmansyah and I. Saidah, "Perancangan web based learning sebagai media pembelajaran berbasis ICT," Informatika, vol. 3, no. September, pp. 176-182, 2016.

[20] J. Juwanda and N. Erlina, "Efektivitas Model Berpikir Berbicara Menulis dengan Media Foto Jurnalistik dalam Pembelajaran Menulis Puisi pada Siswa Kelas VIII SMP," Deiksis J. Pendidik. Bhs. dan Sastra Indones., vol. 6, no. 2, p. 14, 2019, doi: 10.33603/dj.v6i2.1931.

[21] E. Herliyani and L. Bronto Sutrisno, "Pengembangan Media Pembelajaran Berbasis Multimedia Interaktif Pada Mata Kuliah Animasi 1 Bahasan Motion Graphic Jurusan Desain Komunikasi Visual ( Diii ) Undiksha,” PRASI, vol. 11, no. 01, pp. 70-79, 2017.

[22] A. H. Amrulloh, A. eizzi Irsyada, and E. O. Verdiana, "Perancangan Video Informasi Mengenai Asal-Usul Air Terjun Sedudo Nganjuk Dengan Teknik Motion Graphic 2D," J. Desain Komun. Vis. Asia, vol. 2, no. 1, p. 53, 2019, doi: 10.32815/jeskovsia.v2i1.381.

[23] T. Reno, A. U. Siahaan, and A. Alfian, "Implementasi Motion Grafis Video Animasi 2D Untuk Pengenalan Nirmana,” J. Digit. Educ. Commun. Arts, vol. 1, no. 2, pp. 113- 
122, 2018, doi: 10.30871/deca.v1i2.859.

[24] N. D. Arofah and A. Sumitra, "PENGARUH KEMAMPUAN BERPIKIR LOGIS MATEMATIS PADA ANAK USIA DINI DENGAN MENGGUNAKAN MEDIA PEMBELAJARAN LOTTO DI KELOMPOK B," J. Ceria, vol. 2, no. 2, pp. 7-14, 2019.

[25] N. Fatikasari, N. Hidayah, M. Nurul, M. Wardana, and P. A. Sofie, "Prosiding National Seminar on Accounting, Finance, Pengembangan Media Pembelajaran PowerPoint Berbasis Microsoft 365 Dalam Meningkatkan Efektifitas Pembelajaran,” 2021, vol. 1, no. 4, pp. 171-178.

[26] R. Fauzyah and E. Franzia, "Motion Graphic Promosi Pasar Papringan Di Temanggung, Jawa Tengah,” J. Dimens. DKV Seni Rupa dan Desain, vol. 3, no. 2, p. 159, 2018, doi: 10.25105/jdd.v3i2.3602.

[27] Y. Efendi, E. Adi, and S. Sulthoni, "Pengembangan Media Video Animasi Motion Graphics pada Mata Pelajaran IPA Di SDN Pandanrejo 1 Kabupaten Malang," JINOTEP (Jurnal Inov. dan Teknol. Pembelajaran) Kaji. dan Ris. Dalam Teknol. Pembelajaran, vol. 6, no. 2, pp. 97-102, 2020, doi: 10.17977/um031v6i22020p097.

[28] E. Sumarsih, M. Widodo, and E. Suyanto, "J-SIMBOL (Bahasa, Sastra, dan Pembelajarannya)," J-SIMBOL (Bahasa, Sastra, dan Pembelajarannya), vol. 5, no. 1, pp. 1-9, 2017.

[29] N. Isnaeni and D. Hildayah, "Media Pembelajaran Dalam Pembentukan Interaksi Belajar Siswa," J. Syntax Transform., vol. 1, no. 5, pp. 148-156, 2020.

[30] A. Roffiq, I. Qiram, and G. Rubiono, "Media Musik Dan Lagu Pada Proses Pembelajaran," JPDI (Jurnal Pendidik. Dasar Indones., vol. 2, no. 2, p. 35, 2017, doi: 10.26737/jpdi.v2i2.330. 